\title{
Preliminary phytochemical analysis and in vivo antimalarial activity of the crude extracts of the leaf of African mistletoe Tapinanthus dodoneifolius against Plasmodium berghei in Mice
}

\begin{abstract}
Malaria is caused by a protozoan parasite of the genus plasmodium. Common species associated with human malaria include parasites like $P$. Vivax, $P$. falciparum, $P$. ovale, $P$. malariae and $P$. Knowlesi in some cases. The disease poses a significant threat to public health worldwide. Factors like high cost, toxicity, absence of vaccines hinders the malarial control. The leaves of Tapinanthus dodoneifolius were obtained aseptically from Parkia biglobosa, air-died and crude extracts were prepared by soxlet extraction in the presence of acetone and ethanol as solvents. Phytochemical screening of the extracts was performed before treating P.berghei ininfected mice. The antiplasmodial activity was determined by parasitaemia count through microscopy. Results were expressed as Mean and Standard Error of Mean accompanied by Ducan's Mutlple comparison test. Phytochemical constituents of the extracts identified include: Alkaloids, Flavinoids, Carbohydrates, Fats and Oils, Proteins, Phytosterols, Saponins, Phenolic Compounds and Tanins. The leaves crude extracts were nontoxic to mice while their antiplasmodial activity dose dependent. The Parasitaemia of the treated mice responded positively, resulting in a significant decrease of parasitaemia from the $3^{\text {rd }}$ day to the $5^{\text {th }}$ day. The mean survival time of the mice were enhanced by acetone and ethanol extracts respectively. The leaves of Tapinanthus dodoneifolius possess anti plasmodial activity and can be used as alternative source for treating malaria. Hygienically prepared extracts of the leaves for medicinal use is safe for consumption. However, further investigations regarding their safety are necessary.
\end{abstract}

Keywords: malaria, plasmodium, phytochemical, mice, mistletoe
Volume 5 Issue $6-2017$

\author{
Shuaib Maryam Eyya,' Dadah John Anthony,' \\ Yushau Muhammad, ${ }^{2}$ Waje Timothy' \\ 'Department of Microbiology, Kaduna State University, Nigeria \\ ${ }^{2}$ Department of Microbiology, Bayero University, Nigeria
}

Correspondence: Eyya Shuaib Maryam, Department of Microbiology Kaduna State University P.M.B.2339, Kaduna, Nigeria,Tel 234809408I53I, Email handm.0763@gmail.com

Received:September 12, 2017 | Published: September 28, 2017
Abbreviations: NIMRL, national institute for medical research lagos; SEM, standard error of mean; MST, mean survival time

\section{Introduction}

The global burden of malaria has been reported to be critical and has been validated through significant records of morbidity and mortality especially in the tropics. ${ }^{1}$ Commonly referred to as a tropical disease, it is an issue of serious health concern in Sub-Saharan African population where the disease severity is high resulting in hospitalization and deaths in children and pregnant women. ${ }^{2-4}$ In Nigeria, about $60 \%$ of outpatients' attendance and $30 \%$ of hospital admissions are victims of the disease..$^{5}$ The etiologic agents are the protozoan parasites belonging to the genus Plasmodium which includes Plasmodium falciparum, Plasmodium vivax, Plasmodium ovale, Plasmodium malariae and Plasmodium kowlesi in some cases which are responsible for causing malaria in humans. ${ }^{6}$ These parasites are transmitted by the female Anopheles mosquito which breeds more in tropical areas with suitable weather and climatic conditions for their survival. ${ }^{7}$ The development of the parasite in the human host involves hepatocytes and red blood cells respectively. ${ }^{6}$

In vivo studies of Plasmodium berghei has revealed a similarity in their structure and gene content with the human malaria parasites. The study also revealed the ease at which its genome can be subjected to genetic modifications. ${ }^{8,9}$ Common symptoms associated with malaria are fever, chills, sweats, headache, body malaise, nausea and vomiting but in severe cases it could lead to anaemia, Hemoglobinuria, low blood pressure, acute kidney failure, hyper parasitaemia, metabolic acidosis, hypoglycaemia. ${ }^{9}, 10$ The control of malaria has been a global challenge due to the high costs of antimalarial drugs, enhanced plasmodial resistance, poor quality drugs and lack of effective malaria vaccine. ${ }^{10,11}$ Therefore, the alternative sources for treating malaria have become evident and cannot be denied. Plants which have been used for centuries as alternative sources of medicine particularly in Africa need to be explored for anti malaria activity in order to counteract the challenges associated with the disease. ${ }^{12}$ Moreover, medicinal plants and herbs constitute most of the plant sources for the production of useful drugs that are being used by humans throughout the world. ${ }^{13}$ Mistletoes, often regarded as hemi-parasitic plants of the families Loranthaceae and Viscaceae have served many medicinal purposes in most continents of the world. ${ }^{14}$ They have been used in folklore medicine since ancient times but today serve as remedies for a broad spectrum of diseases including high blood pressure, arteriosclerosis, hypertension, hysteria, cancer and other conditions associated with the immune system. ${ }^{15-17}$ The African mistletoe, Tapinanthus dodoneifolius belongs to the Loranthaceae family and grows on many plants including Parkia biglobosa. In Nigeria, it has been used for the treatment and management of wounds, epilepsy, hepatitis, dysentery, diabetes, diarrhoea as well as an antimicrobial agent against many microorganisms. ${ }^{18,19}$ Therefore, its phytochemicals and in vivo antiplasmodial activity were investigated with the aim of determining its safety and ability to serve as an alternative 
source of treating malaria. This research sought to identify and evaluate the potential constituents of the leaf extracts of Tapinanthus dodoneifolius (host plant Parkia biglobosa) as well as their antimalarial activity. This is with a view of establishing a basis for use of the plant material as a cheap, safe, effective and available alternative for the treatment of malaria which can be used to reduce the disease burden thereby improving public health.

\section{Materials and methods}

\section{Collections, authentication and processing of the plant material}

The leaves of the African mistletoe Tapinanthus dodoneifolius were harvested aseptically from the host plant Parkia biglobosa into sterile polythene bags. The host plants were authenticated at the Herbarium of the Department of Botany, Ahmadu Bello University, Zaria, Kaduna State, Nigeria with the following details

Family of the leaves for study -Loranthaceae:

I. Specie: Tapinanthus dodoneifolius (voucher number 1175).

II. Family of the host plant: Mimosaceae

\section{Species: Parkia biglobosa (Voucher number 2846.)}

The leaves of Tapinanthus dodoneifolius were transported to the Medical Microbiology Laboratory of Kaduna State University for processing. They were carefully dried under shade to minimize loss of volatile constituents through high temperatures and pulverised aseptically using a mortar and pestle. ${ }^{20}$ The crude extracts of the leaves were prepared from the powdered leaves by Soxlet extraction using Acetone and Ethanol respectively as solvents and subjected to concentration and evaporation, retaining the extracted compounds. ${ }^{21}$

\section{Preliminary phytochemical tests on ethanol and acetone extracts}

The following tests for secondary metabolites were carried out in both ethanol and acetone extracts respectively.

a. Wagner's test and Dragendroff's test for Alkaloids.

b. Molish's test for Carbohydrates.

c. Sheet of filter paper test for fixed oils and fats.

d. Ferric Chloride test for Phenolic Compounds and tannins.

e. Alkaline Reagent test for Flavinoids.

f. Libberman- Burchards test for phytosterols

g. Millon's test for proteins.

h. Test for saponins. ${ }^{22,23}$

\section{Acute toxicity test}

Healthy female Wista Albino mice weighing 100-190g were used for the Acute Toxicity Test. Weights were taken before and after dosing. A total of 24 animals were used for the determination of the acute toxicity dose using the ethanol and acetone extracts. All the Animals were observed after the first thirty (30) minutes after dosing, for four hours, and periodically during the first 24 hours. There was no mortality for ethanol and acetone extracts in phase 1 and Phase 2 of the acute toxicity test. Animals were observed for overall signs of toxicity such as slow movement, fast breathing, lethargy and restlessness. ${ }^{23}$

\section{Experimental animals and malaria curative test}

Healthy 7-8 weeks old female Swiss Albino mice weighing 13$27 \mathrm{~g}$ were used for the malaria studies. Animals were weighed before inoculation and prior to treatment. Animals were allowed to acclimatize for 24 hours at room temperature and kept at room temperature housed in standard shoe box cages. They were fed with commercial feeds and treated water freely. The Animals were grouped and distinguished by markings at the tail. The Room was adequately lit and ventilated. The Animals were injected interperitoneally with standard inocula of Chloroquine Sensitive Plasmodium berghei infecting erythrocytes using a sterile $1 \mathrm{ml}$ syringe. This Parasite was obtained from the National Institute for Medical Research Lagos (NIMR) and maintained at the Animal House of Pharmacology Department at Ahmadu Bello University Zaria. The normal control group was left out. Infection was allowed to establish for 72 hours..$^{24,25}$

Negative control group: Animals were inoculated with approximately $0.2 \mathrm{mls}$ of parasitized erythrocytes and no treatment given.

Positive control group: Animals were inoculated with $0.2 \mathrm{ml}$ parasitized erythrocytes and treated with $5 \mathrm{mg} / \mathrm{ml}$ Chloroquine Phosphate injection.

\section{Acetone extract treated groups}

Group I were inoculated with approximately $0.2 \mathrm{mls}$ of parasitized erythrocytes and treated with $1000 \mathrm{mg} / \mathrm{kg}$ Acetone extract.

Group II were inoculated with approximately $0.2 \mathrm{mls}$ of parasitized erythrocytes and treated with $500 \mathrm{mg} / \mathrm{kg}$ Acetone extract.

Group III were inoculated with approximately $0.2 \mathrm{mls}$ of parasitized erythrocytes and treated with $250 \mathrm{mg} / \mathrm{kg}$ Acetone extract.

\section{Ethanol extracts treated groups}

Group I were inoculated with approximately $0.2 \mathrm{mls}$ of parasitized erythrocytes and treated with $1000 \mathrm{mg} / \mathrm{kg}$ Ethanol extract.

Group II were inoculated with approximately $0.2 \mathrm{mls}$ of parasitized erythrocytes and treated with $500 \mathrm{mg} / \mathrm{kg}$ Ethanol extract.

Group III were inoculated with approximately $0.2 \mathrm{mls}$ of parasitized erythrocytes and treated with $250 \mathrm{mg} / \mathrm{kg}$ Ethanol extract.

The extracts and chloroquine were administered orally via an intubation cannula concurrently twice daily as curatives before feeding the animals. They were kept for 28 days post inoculation and the mean survival time for each group was determined. Thin blood films were made from the tail of each mouse after 72 hours of infection and 72 hours treatment and stained with field stain for microscopy. ${ }^{26,27}$ Mean survival time $=$ Total days of survival of each animal in the group/ Total number of animals in the group.

\section{Parasitaemia count and data analysis}

A minimum of three (3) fields of view on the microscope were used to obtain the total parasitized and non-parasitized erythrocytes and subsequently the percentage of infected cells in each group. Results were expressed as mean percentage parasitaemia for the three different fields. The data of the study was expressed as Mean and Standard Error of Mean (SEM) for each group. The data on parasitaemia and Mean Survival Time (MST) were analyzed using SPSS version 20.0. The difference between the mean of measured parameters were compared using one way ANOVA followed by Duncan's Multiple Comparison Test at $5 \%$ level of significance $(\mathrm{P}<0.05){ }^{27}$ 


\section{Results}

The Preliminary phytochemical tests for the ethanol and acetone extracts revealed the presence of alkaloids, carbohydrates, fixed fats and oils, phenolic compounds and tanins, flavonoids, phytosterol, proteins and saponins. Proteins, fixed fats and oils were present in ethanol extract but absent in acetone extract (Table 1). Table 2 shows the Microbial analysis carried out to determine the microbial safety of the crude extracts (Purity test) on the test animals. The ethanol extract revealed colony forming units of $0.1 \times 10^{1}$ each for aerobic mesophillic bacteria and mould counts respectively. The acetone extract showed $0.3 \times 10^{1} \mathrm{CFU}$ for aerobic mesophillic bacteria and $0.1 \times 10^{1} \mathrm{CFU}$ for mould counts. Both extracts were free from contamination with Escherichia coli, Staphyllococcus, Pseudomonas aeroginosa. Furthermore, phase 1 and 2 of the experiment revealed
$100 \%$ survival of the animals to the different concentrations of ethanol and acetone leaf extracts respectively. There were no signs of toxicity or distress during the 24 hour period in both phase 1 and Phase 2 of the experiment.

The weights of $P$. berghei infected mice before and after different treatments revealed varying weight changes. Infected but not treated mice (negative control) showed 2.08\% weight loss after day 5 while chloroquine treated mice (positive control) revealed a weight gain of $1.32 \%$ after treatments. The mice treated with ethanol extract showed different weight gain as follows: Group I (27.35\%), Group II (9.81\%) and Group III (2.08\%). The weigh gains of the acetone extract treated mice include: Group I (11.46\%), Group II (11.11\%) and Group III $(6.59 \%)$ (Table 3$)$

Table I Preliminary Phytochemicals on Ethanol and Acetone Extracts of the Leaves of Tapinanthus dodoneifolius

\begin{tabular}{|c|c|c|c|c|c|c|}
\hline \multirow{2}{*}{ Constituents } & \multirow{2}{*}{$\begin{array}{l}\text { Phytochemical test } \\
\text { Meyer's Test }\end{array}$} & \multicolumn{5}{|c|}{ Acetone extract Ethanol extract } \\
\hline & & & ++ & & + & \\
\hline \multirow[t]{2}{*}{ Alkaloids } & Wagner's Test & & ++ & & + & \\
\hline & Dragendoff's Test & & & ++ & & + \\
\hline Carbohydrates & Molish's Test & & ++ & & + & \\
\hline Fixed oils and Fats & Paper Test & & & - & & + \\
\hline Phenolic compounds and Tanins & Ferric Chloride Test & ++ & & + & & \\
\hline Flavinoids & Flavinoid Test & & ++ & & + & \\
\hline Phytosterols & Liberman-Burchards Test & ++ & & + & & \\
\hline Proteins & Millions Test & & - & & + & \\
\hline Saponin & Frothing Test & & ++ & & + & \\
\hline
\end{tabular}

Key: +, positive; -, negative; ++:,strongly positive

Table 2 Microbial Safety of Ethanol and Acetone Leaf Extracts of Tapinanthus dodoneifolius (Purity Test)

\begin{tabular}{|c|c|c|c|c|c|c|}
\hline \multirow{2}{*}{ Microorganisms } & \multicolumn{3}{|c|}{ Ethanol extracts } & \multicolumn{3}{|c|}{ Acetone extracts } \\
\hline & Plate A (CFU) & Plate B (CFU) & Plate C(CFU) & Plate A(CFU) & Plate B (CFU) & Plate C (CFU) \\
\hline \multicolumn{7}{|l|}{ Aerobic } \\
\hline Mesophillic & $0.1 \times 101$ & $<|X| 0 \mid$ & $<|X| 0 \mid$ & $0.3 \times 101$ & $<|X| 0 \mid$ & $<|X| 0 \mid$ \\
\hline \multicolumn{7}{|l|}{ Bacteria } \\
\hline $\begin{array}{l}\text { Fungal/Mould } \\
\text { Count }\end{array}$ & $0.1 \times 101$ & $<|X| 0 \mid$ & $<|X| 0 \mid$ & $0.1 \times 101$ & $<|X| 0 \mid$ & $<|X| 0 \mid$ \\
\hline E. coli & Nil & Nil & $\mathrm{Nil}$ & Nil & Nil & Nil \\
\hline S. aureus & Nil & Nil & Nil & Nil & Nil & Nil \\
\hline P. aeroginosa & Nil & $\mathrm{Nil}$ & $\mathrm{Nil}$ & Nil & Nil & Nil \\
\hline
\end{tabular}

Table 3 Weights of $P$. berghei Infected Mice Before and After Administration of Different Treatments

\begin{tabular}{|c|c|c|c|c|c|c|c|c|}
\hline & \multirow{2}{*}{$\begin{array}{l}\text { Negative } \\
\text { control mice }\end{array}$} & \multirow{2}{*}{$\begin{array}{l}\text { Positive } \\
\text { control mice }\end{array}$} & \multicolumn{3}{|c|}{ Ethanol extracts } & \multicolumn{3}{|c|}{ Acetone extracts } \\
\hline & & & Group I & Group II & Group III & Group I & Group II & Group III \\
\hline Treatments & Not Treated & $\begin{array}{l}\text { Chloroquine } \\
5 \mathrm{mg} / \mathrm{kg}\end{array}$ & $1000 \mathrm{mg} / \mathrm{kg}$ & 500 mg/kg & $250 \mathrm{mg} / \mathrm{kg}$ & 1000 mg/kg & 500 mg/kg & $250 \mathrm{mg} / \mathrm{kg}$ \\
\hline $\begin{array}{l}\text { Weight of } \\
\text { Mice on Day } 0 \\
(\mathrm{M} \pm \text { SEM)g }\end{array}$ & $19.20 \pm 2.50$ & $18.80 \pm 1.59$ & $17.00 \pm 0.63$ & $22.00 \pm 1.10$ & $18.80 \pm 2.22$ & $17.00 \pm 0.45$ & $19.20 \pm 0.73$ & $17.00 \pm 0.63$ \\
\hline $\begin{array}{l}\text { Weight of } \\
\text { Mice after Day } 5 \\
(\mathrm{M} \pm \text { SEM)g }\end{array}$ & $18.80 \pm 2.20$ & $19.20 \pm 0.92$ & $23.40 \pm 1.29$ & $24.40 \pm 1.03$ & $19.20 \pm 2.50$ & $19.20 \pm 0.66$ & $21.60 \pm 0.93$ & $18.20 \pm 0.73$ \\
\hline \%Weight Gain & $2.08 \%$ loss & $1.32 \%$ & $27.35 \%$ & $9.81 \%$ & $2.08 \%$ & II.46\% & $11.11 \%$ & $6.59 \%$ \\
\hline
\end{tabular}

Key: M, mean; SEM, standard error of mean

The antiplasmodial activity of ethanol and acetone leaf extracts of Tapinanthus dodoneifolius on the parasitized mice was dosedependent. Table 4 shows the parasitaemia levels on the mice at varying oral doses and extract concentrations compared to chloroquine and negative control during an early Plasmodium berghei infection. The result shows significant differences in chemo-supression $(\mathrm{P}<0.05)$ between chloroquine and ethanol extract at $1000 \mathrm{mg} / \mathrm{kg}(86.88 \%)$, $500 \mathrm{mg} / \mathrm{kg}(68.95 \%)$ while acetone extracts were $1000 \mathrm{mg} / \mathrm{kg}$ $(88.90 \%), 500 \mathrm{mg} / \mathrm{kg}(73.11 \%)$ respectively. However, ethanol extract at $250 \mathrm{mg} / \mathrm{kg}(93.4 \%)$ and acetone extract at $250 \mathrm{mg} / \mathrm{kg}(93.81 \%)$ showed the highest chemosupression which were close to that of chloroquine (97.34\%). 
Table 5 shows the degree of parasitaemia for the different treatments using the Duncan's Comparison Test. The parasitaemia values which showed significant difference with the controls were marked. Parasitaemia level decreased remarkably from day 3 of the treatments among all treated groups. Chloroquine showed similar anti-plasmodial activity on day 3 .

The average (Mean) survival time for the rats in the negative control group was 6.8 days with 5 dead mice. On the other hand, mice in the positive control group had a mean survival time of 28 days without any deaths. Mice treated with acetone extract at $250 \mathrm{mg} / \mathrm{kg}$ recorded 5 deaths with a mean survival time of 17 days while those treated with ethanol extract at $1000 \mathrm{mg} / \mathrm{kg}$ recorded the least number of dead rats (1) with a mean survival time of 25 days. The acetone extract treated mice at $250 \mathrm{mg} / \mathrm{kg}$ had the highest chemo-supression of $93.81 \%$ as well as number (5) of dead animals (Table 6).

Table 4 Anti-Plasmodial Activity of Crude Extracts of the leaves of Tapinanthus dodoneifolius on Parasitized Mice

\begin{tabular}{|c|c|c|c|c|c|c|c|c|}
\hline & \multirow{2}{*}{$\begin{array}{l}\text { Negative } \\
\text { control mice }\end{array}$} & \multirow{2}{*}{$\begin{array}{l}\text { Positive } \\
\text { control mice }\end{array}$} & \multicolumn{3}{|c|}{ Ethanol extracts } & \multicolumn{3}{|c|}{ Acetone extracts } \\
\hline & & & Group I & Group II & Group III & Group I & Group II & Group III \\
\hline Treatments & Not treated & $\begin{array}{l}\text { Chloroquine } \\
5 \mathrm{mg} / \mathrm{kg}\end{array}$ & $\begin{array}{l}1000 \\
\mathrm{mg} / \mathrm{kg}\end{array}$ & $\begin{array}{l}500 \\
\mathrm{mg} / \mathrm{kg}\end{array}$ & $\begin{array}{l}250 \\
\mathrm{mg} / \mathrm{kg}\end{array}$ & $\begin{array}{l}1000 \\
\mathrm{mg} / \mathrm{kg}\end{array}$ & $\begin{array}{l}500 \\
\mathrm{mg} / \mathrm{kg}\end{array}$ & $\begin{array}{l}250 \\
\mathrm{mg} / \mathrm{kg}\end{array}$ \\
\hline $\begin{array}{l}\text { Parasitaemia } \\
(\mathrm{M} \pm \mathrm{SEM})\end{array}$ & $23.32 \pm 13.05$ & $0.62 \pm 0.52$ & $3.05 \pm 4.55$ & $7.24 \pm 13.08$ & $1.53 \pm 0.95$ & $2.58 \pm 3.58$ & $6.27 \pm 10.24$ & $1.44 \pm 0.39$ \\
\hline $\begin{array}{l}\text { Chemo- } \\
\text { Suppression (\%) }\end{array}$ & 0 & 97.34 & 86.88 & 68.95 & 93.4 & 88.9 & 73.11 & 93.81 \\
\hline
\end{tabular}

Key: M, mean; SEM, standard error of mean.

Table 5 Parasitaemia using Duncan's Multiple Comparison Test at $\mathrm{P}<0.05$

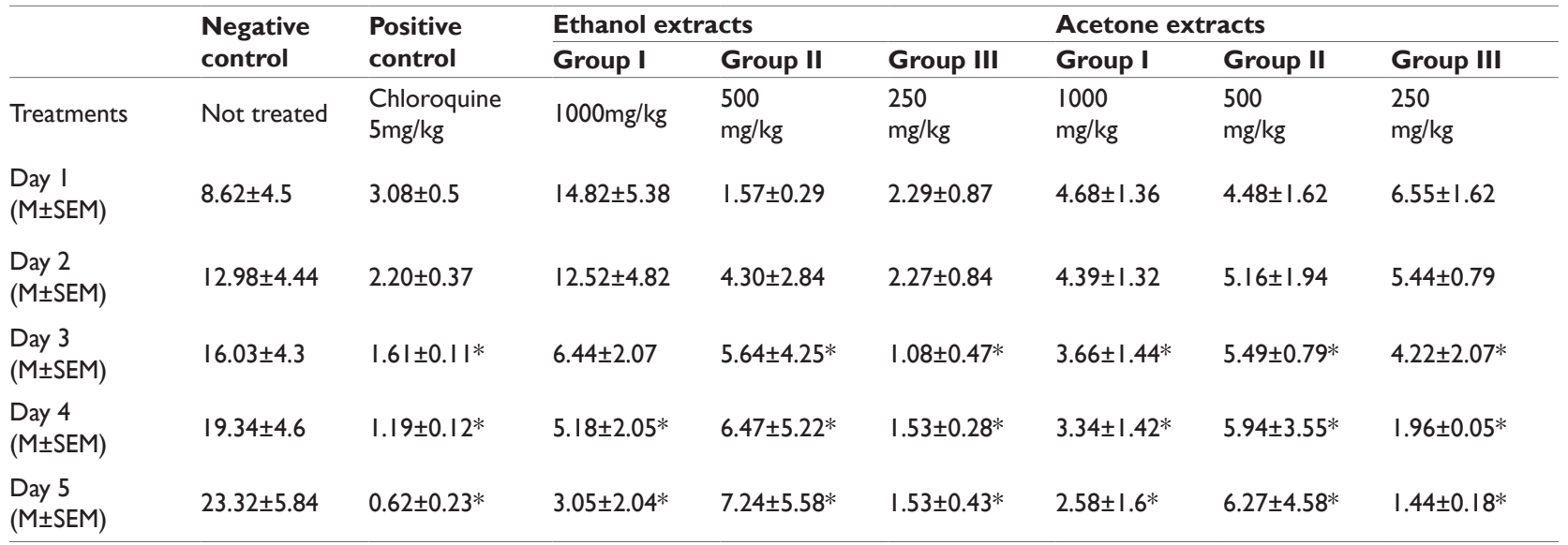

Key: *, Parasitaemia Values significantly different from controls $(\mathrm{P}<0.05)$.

M, mean; SEM, standard error of the mean

Table 6 Mean Survival Time and Number of Dead Mice across the Groups

\begin{tabular}{|c|c|c|c|c|c|c|c|c|}
\hline \multirow{2}{*}{ Groups } & \multirow{2}{*}{$\begin{array}{l}\text { Negative } \\
\text { control }\end{array}$} & \multirow{2}{*}{$\begin{array}{l}\text { Positive } \\
\text { control }\end{array}$} & \multicolumn{3}{|c|}{ Ethanol extracts } & \multicolumn{3}{|c|}{ Acetone extracts } \\
\hline & & & Group I & Group II & Group III & Group I & Group II & Group III \\
\hline $\begin{array}{l}\text { Concentrations/ } \\
\text { Dosage }\end{array}$ & Not treated & $\begin{array}{l}\text { Chloroquine } \\
5 \mathrm{mg} / \mathrm{kg}\end{array}$ & $1000 \mathrm{mg} / \mathrm{kg}$ & $\begin{array}{l}500 \\
\mathrm{mg} / \mathrm{kg}\end{array}$ & $\begin{array}{l}250 \\
\mathrm{mg} / \mathrm{kg}\end{array}$ & $\begin{array}{l}1000 \\
\mathrm{mg} / \mathrm{kg}\end{array}$ & $\begin{array}{l}500 \\
\mathrm{mg} / \mathrm{kg}\end{array}$ & $\begin{array}{l}250 \\
\mathrm{mg} / \mathrm{kg}\end{array}$ \\
\hline $\begin{array}{l}\text { Mean } \\
\text { Survival } \\
\text { Time (Days) }\end{array}$ & $6.8 \pm 1.64$ & $28 \pm 0.36$ & $27 \pm 0.49$ & $25 \pm 0.36$ & $22 \pm 0.79$ & $20 \pm 1.57$ & $23 \pm 0.34$ & $17 \pm 0.47$ \\
\hline $\begin{array}{l}\text { Number } \\
\text { of Dead Mice }\end{array}$ & 5 & 0 & I & 3 & 3 & 2 & 2 & 5 \\
\hline
\end{tabular}

\section{Discussion}

The growing interests in the use of plants for medicinal purposes have increased over the years due to their easy preparation procedures, cost effectiveness and fewer side effects on animals including humans..$^{28}$ The sources of medicinal plants vary from traditional plants in China to modern horticultural production systems in North
America and Europe. ${ }^{29}$ The seeds, berries, leaves, bark, flowers, roots or extract compounds from medicinal plants commonly known as phyto medicines, could possess a range of therapeutic properties to treat a variety of ailments including allergies, asthma, diabetes, chronic fatigue, cancer as well as malaria. ${ }^{28}$ Many studies on the use of medicinal plants as antimalarials in Africa have reported varying 
results from high promising activities to very low effects against the Plasmodium $s p .{ }^{30}$ Nevertheless, natural products from plants including Tapinanthus dodoneifolius remain a reliable source of phyto-medicines for the treatment of certain ailments. ${ }^{27}$

The presence of phyto-chemicals such as alkaloids, carbohydrate, saponins, flavonoids, phenol compounds and tannins, phystosterols, proteins, fixed fats and oils in the crude leaf extracts of Tapinanthus dodoneifolius, make them a vital source of these constituents also known as secondary metabolites. This agrees with a report of previous study in Nigeria enlisting these compounds as important constituents of leaf extracts of plants belonging to the Loranthaceae family including Tapinanthus $s p .{ }^{31}$ These constituents which are bioactive substances have been associated with diverse physiological and biological activities in vivo including therapeutic effects. ${ }^{32}$ Their presence in the crude plant material enhances pharmacological activities responsible for their therapeutic effects. ${ }^{33,34}$. Comparatively, the phyto-chemicals were more in the acetone leaf extracts than the ethanol extracts probably because they were more soluble in acetone than ethanol since soxlet extraction is based on solubility of a particular solute in a solvent.

The low counts for mesophillic bacteria and moulds as well as absence of E. coli, S. aureus and P. aeroginosa obtained from the purity tests suggest that the crude extracts were free from contamination with pathogenic bacteria and microbial loads were within acceptable limits for consumption. ${ }^{35}$ This confirms that the leaf extract of Tapinanthus dodoneifolius to be used as phyto-medicine is safe for consumption when prepared under hygienic conditions. Acute toxicity test was necessary to investigate the therapeutic potential of the studied plant material as well as any associated adverse effects on the mice. ${ }^{14}$ The absence of mortality and signs of toxicity such as slow movement, fast breathing, lethargy and restlessness on the mice during the toxicity test suggest that the leaves of Tapinanthus dodoneifolius were nontoxic to the mice. This agrees with a previous study on the updates of the chemistry, ethno-pharmacology and medicinal values of African mistletoe (Tapinanthus $s p$ ) reported to be non-toxic to experimental animals. ${ }^{36}$ This suggests that the use of Tapinanthus dodoneifolius for medicinal purposes has more beneficial than harmful effects.

The weight gains experienced by mice treated with ethanol crude extracts could be attributed to the combined therapeutic effects (Antiplasmodial activity) of the extracts as well as the presence of carbohydrate, proteins, fats and oil at high concentrations which are good dietary source of energy and nutrients. On the other hand, anti plasmodial activity and carbohydrates must have contributed in the weight gain of mice treated with acetone extracts since proteins as well as fixed fats and oils were absent. There could have been decrease in parasitaemia due to the presence of alkaloids, tannins, saponnins and flavonoids which have been associated with antiplasmodial activity in vivo. ${ }^{19,37}$ The downward trend in the weight gains with decreasing concentration and dosage for the treated mice for both extracts confirms the weight gains of the mice to be dose dependent. In other word, higher concentration /dosage of the extracts enhances the nutrient contents resulting in weight gain after the treatment. This contradicts a report of previous study on the non dependence of weight gain on the dosage of $A$. abyssinica crude extract on treated mice infected with $P$. berghei. ${ }^{37}$ This difference could be attributed to variation in plant material and solvent used for crude extract preparation. Hence, there is need for caution to avoid excessive dosage of Tapinanthus dodoneifolius in order to prevent negative effects despite the absence of adverse effects associated with the weight gain.
The anti-plasmodial activity of the crude extracts expressed in percentage chemo-suppression of the parasite in vivo revealed in this study is considered good. The highest chemo-suppression observed was among mice treated with ethanol extracts at $250 \mathrm{mg} / \mathrm{kg}(93.40 \%)$ as well as acetone extracts at $250 \mathrm{mg} / \mathrm{kg}(93.81 \%)$. The chloroquine treated mice (positive control) had the highest chemo-suppression (97.34\%) while the negative control mice without any treatment had zero parasitic suppression. Chemo-suppression is classified based on in vivo anti-plasmodial activity of an extract as moderate, good, and very good if it is equal to or greater than $50 \%$ at a dose of $500 \mathrm{mg} /$ $\mathrm{kg}, 250 \mathrm{mg} / \mathrm{kg}$ and $100 \mathrm{mg} / \mathrm{kg}$ body weight per day respectively. ${ }^{38}$ This is contrary to a report of previous study on increased anti-plasmodial activity with increasing extract concentration where water and methanol were used as the solvents for extract preparation. ${ }^{39}$ These different observations could probably be attributed to variations in the solvents used for preparation of the respective crude extracts of the plant material. The solvent polarity is important in crude extract preparations as it determines the riches of the constituents of an extract in the crude state. The chemo suppression of Plasmodium berghei in vivo observed in this study agrees with previous report of high chemosuppression $(79.17 \%, 81.67 \%$ and $85 \%)$ of $P$. berghei by methanol crude extract of whole plant Tapinanthus dodoneifolius. ${ }^{19}$ Thus, the leaf of Tapinanthus dodoneifolius contained substances which are considered active because of their ability to reduce parasitaemia by more than $30 \%$. Therefore, it can be used as anti malarials because of its activity in vivo. ${ }^{40}$

The decrease in parasitaemia levels across all the groups from day three down to the fifth day of treatments suggests the need for consistency in the use of medicinal plants as anti malarials. Furthermore, the significant difference in parasitaemia $(\mathrm{P}<0.05)$ across the treatment groups in comparison with the negative control (Duncans's Multiple comparison Test) confirms a progressive degeneration of the parasites as treatments progressed.

The decrease in parasitaemia of the treated mice suggest that both acetone and ethanol leaf extracts of Tapinanthus dodoneifolius possessed blood schizoncidal activity and therefore had anti- malarial activity revealed through suppression of the Plasmodium berghei in vivo. Thisreduced the overall pathologic effect of the parasites on the studied mice thereby increasing their average survival time. This agrees with reports of previous studies on the effects of Tapinanthus dodoneifolius on the average survival time of treated mice infected P. berghei. ${ }^{19}$ This agreement is due to the ability of the plant extracts to prolong the mean survival time of the treated mice infected with Plasmodium berghei in comparison with the negative control with the highest number of dead mice (5).

\section{Conclusions and recommendations}

The ethanol and acetone leaf extracts of Tapinanthus dodoneifolius possesed phytochemicals such as alkaloids, carbohydrates, proteins, fats and oils, phytosterols, saponins, flavonois, phenolic compounds and tannins. These bioactive substances play a key role in weight changes and antiplasmodial activity. The extracts were non toxic and presented good anti plasmodial activity on mice infected with Plasmodium berghei. This study confirms the reports of earlier studies on the progressive degeneration of malaria through decreasing parasitaemia and prolongs survival by consistent treatments.

Therefore, more studies need to be carried out on the medicinal values of the African mistletoe Tapinanthus dodoneifolius including its antimalarial activity. Hence it is vital when it comes to the 
efficacy in counteracting malaria and further analysis in terms of identification, purification and concentration of the most active substances from the plant with a view of possible commercialization is significant. However, further research is necessary to evaluate the efficacy, toxicity and bio safety of the plant as an alternative source of malaria treatments. The public need to be enlightened and re-oriented by experts on the use of plant materials as alternatives therapeutic substances.

\section{Acknowledgments}

None.

\section{Conflicts of interest}

We declare that no author had any conflict of interest.

\section{Funding}

None.

\section{References}

1. WHO. Malaria Prevention. World Health Organization, Switzerland. 2017 .

2. Quattara Y, Sanon S, Traore Y, et al. Antimalarial activities of Swartzia madagascarien-sis Desv.(Leguminosae) and Combretum glutinosum Guill and Perr. (Combretaceae) and Tinosporabakis Miers (Menisperma-ceae). Burkina Faso Medicinal plants. African J Trad Complem and Alt Med. 2006;3(1):75-81.

3. Molta BN, Oguche S, Pam DS, et al. Efficacy of a single-dose of amodiaquine co-dministered with sulfadoxine/pyrimethamine combination against $P$. falciparum infection in an area of multidrug resistant malaria in Barikin Ladi, North Central Nigeria. $J$ Pharm and Biores. 2006;3(1):1-6.

4. Efferth T, Kuete V. Cameroonian medicinal plants:pharmacology and derived Natural Products. Front Pharmacol. 2010;1(123):1-19.

5. Samdi LM, Ajayi JA, Oguche S, et al. Seasonal Variation of Malaria Parasite Density in Paediatric Population of North Eastern Nigeria. Global J of Health Sci. 2012;4(2):103-109.

6. https://www.cdc.gov/dpdx/malaria/index.html

7. Moreno JE, Rubio-Palis Y, Paez E, et al. Abundance, biting behaviour and parous rate of anopheline mosquito species in relation to malaria incidence in gold-mining areas of southern Venezuela. Med Vet Entomol. 2009;21(4):339-349.

8. Uzureau P, Barale JC, Janse C, et al. Gene targeting demonstrates that the Plasmodium berghei subtilisin PbSUB2 is essential for red cell invasion and reveals spontaneous genetic recombination events. $\mathrm{Cel}$ Biol. 2004;6(1):65-68.

9. Augustijn KD, Kleemann R, Thompson J, et al. Functional Characterization of the Plasmodium falciparum and $P$. berghei Homologues of Macrophage Migration Inhibitory Factor. Infect Immun. 2006;75(3):1116-1128.

10. https://www.cdc.gov/malaria/about/disease.html

11. Chrubasik C, Jacobson RL. The Development of Artemisinin Resistance in Malaria:Reasons and Solutions. Physiotherap Res. 2010;24(7):1104 1106.

12. Viroj W. Antimalarial Drug and Renal Toxicity. J Nephropharmacol. 2016;5(1):11-12.

13. Ekhaise FO, Ofoezie VG, Enobakhare DA. Antibacterial Properties and Preliminary Phytochemical anaylsis of Methalonic extract of mistletoe (Tapinanthus bangwensis). Bayero $J$ pure and applied sci. 2010;3(2):65-68.
14. Parasuraman S. Toxicological Screning. JPharmacol and Pharmacother. 2011;2(2):74-79.

15. Jadhav N, Patil CR, Chaudhari KB, et al. Diuretic and Natriuretic activities of two mistletoe species in rats. Phamacognosy Res. 2010;2(1):50-57.

16. Fang Y, Guang zhong D, Ai qing C, et al. Study on the Mechanism of Compound Mistletoe Fluid extract in Relieving Hypertension. J Trad Chinese Med. 2009;29(4):291-294.

17. Taiga A. Quantitative phytochemical properties of mistletoe. Res J Agric and Environ Management. 2013;2(6):150-153.

18. Kilham K. Medicinal attributes of mistletoe. Fox News health. 2013.

19. Abdullahi Z, Anuka JA, Salawu AO, et al. In-vivo antiplasmodial activity of methanol whole plant extracts of Tapinanthus dodoneifolius (DC) Danser in mice. African J Pharm and Pharmacol. 2015;9(3):936-942.

20. Rocha RP, Melo EC, Radünz LL. Influence of drying process on the quality of medicinal plants:A review. $J$ Med Plants Res. 2011;5(33):7076-7084.

21. Jensen WB. The origin of the Soxhlet Extractor. J Chem Educ. 2007;84(12):1913.

22. Egwaikhide PA, Okeniyi SO, Gimba CE. Screening for Antimicrobial Activity and Phytochemical constituents of some Nigerian Medicinal Plants. Adv in Biolog Re. 2007;1(5-6):155-158.

23. Trease EG, Evans WC. Trease and Evans Pharmacognosy. Bailliere Tindall Ltd, UK. 2002

24. Enye JC, Chineke HN, Onubeze DP, et al. Wound Healing Effect of Methanol Leaf Extract of Napoleona Vogelii Family (Lecythidaceae). IOSR J Dental and Med Sciences. 2013;8(6):31-34.

25. Petros Z, Melaku D. In-vivo Anti- Plasmodial activity of Adhatoda chimperiana leaf extract in mice. Pharmacol Online. 2012;95-105.

26. Lee G, Goosens AK. Sampling Blood from the Lateral Tail Vein of the Rat. J Visualized Exp. 2015;99:1-5.

27. Tarkang AP, Okalebo AF, Ayong SA, et al. Anti-malarial activity of a polyherbal product (Nefang) during early and established Plasmodium infection in rodent models. Malar J. 2014;13:456.

28. Hai NV. The use of medicinal plants as immunostimulants in aquaculture: A review. J aquaculture. 2015;446:88-96.

29. Schmidt MB. Responsible Use of Medicinal Plants for Cosmetics. Hort Science. 2012;47(8):985-991.

30. Lawal B, Shittu OK, Kabiru AY, et al. Potential antimalarials from African natural products:A review. $J$ Intercul Ethnopharmacol. 2015;4(4):318-343

31. Ibrahim AJ, Egharevba OH, Iliya I, et al. Chemical Profiles as Chemotaxonomic Tools for Loranthaceae in Nigeria. African J Plant Sci. 2014;8(7):343-352.

32. Fasola TR, Inyamah CP. Comparing the Phytochemical components of some plants used in the treatment of malaria. J Pure Appl Sci Tech. 2014;21(1):1-11.

33. Tor-Anyiin AT, Danisa AK. Phytochemical Screening of a vended antimalarial. Indonesian Global J Pharm Sci. 2012;2(2):98-102.

34. Ginsburg H, Deharo E. A call for using natural compounds in the development of new antimalarial treatments - an introduction. Malar J. 2011;10(S1):1-7.

35. https://www.edqm.eu/

36. Adesina SK, Illoh HC, Johnny II, et al. African Mistletoes (Loranthaceae); Ethnopharmacology, Chemistry and Medicinal Values:an Update. African J Trad Comp and Alt Med. 2013;10(3):161-170. 
37. Adugna M, Feyera T, Taddese W, et al. In Vivo Antimalarial Activity of Crude Extract of Aerial Part of Artemisisia abyssinica against Plasmodium berghei in mice. Global J Pharmacol. 2014;23(2):460-468.

38. Bantie L, Assefa S, Teklehaimanot T, et al. In vivo antimalarial activity of the crude leaf extract and solvent fractions of Croton macrostachyus Hocsht. (Euphorbiaceae) against Plasmodium berghei in mice. BMC Complement Altern Med. 2014;14:79.
39. Builders MI, Oguru MO, Aguiyi C. Antiplasmodial Potential of the African Mistletoe:Agelanthus dodoneifolius Polh and Wiens. Indian $J$ Pharm Sci. 2012;74(3):223-229.

40. Krettli AU, Adebayo JO, Kretti LG. Testing of Natural Products and Synthetic Molecules Aiming at New Antimalarials. Curr Drug Targets. 2009;10(3):261-270. 